\title{
Chapter 1. Place and Landscape in Comparative Austronesian Perspective
}

\author{
James J. Fox
}

\section{Introduction}

The papers that comprise this volume examine ways in which social knowledge is framed and vested in particular landscapes. Each paper describes a specific Austronesian locality and considers both the cultural creation of this setting and the ways in which knowledge is maintained, transformed and remembered in relation to it.

Each account is focused on a separate Austronesian-speaking population. These populations are located over a wide area stretching from Madagascar to Melanesia with languages representative of currently recognized major subgroups of the Austronesian language family: West Malayo-Polynesian, Central Malayo-Polynesian and Eastern Malayo-Polynesian, including speakers of both the Southwest Halmahera-West New Guinea and the Oceanic subgroups. The strategic purpose of this collection is to carry forward the comparative enterprise begun under the auspices of the Comparative Austronesian Project of the Research School of Pacific and Asian Studies. As such, this volume forms part of a series that has explored various comparative topics and each has featured a different array of Austronesian-speaking groups.

The intention is to give impetus to a comparative perspective that takes into account the whole of the Austronesian-speaking world. Identifying what may be common to all of the Austronesian peoples and what are critical cultural innovations in different regions is an essential part of this effort. The differentiation of Austronesian languages among and within regions is as fundamental as is a general perspective on the language family as a whole.

Among linguists, a great deal of work on the subgrouping of Austronesian languages remains to be done, especially within the large provisionally-constructed subgroup known as Central Malayo-Polynesian which covers a considerable area of eastern Indonesia and provides linkages from west to east. In many cases, in eastern Indonesia, given the time depth for the Austronesian penetration of the area and the possibilities of movement among numerous islands, speakers of languages who are now contiguous may represent different migratory movements. Recognition of these historical differences among Austronesian populations is as important as is the recognition of broadly shared commonalities. 
Equally important to this comparative effort, especially for anthropologists, is the task of creating a mode of analysis that will establish the basis of a comparative discourse appropriate to examination of the whole range of Austronesian societies. Such a discourse is needed to provide theoretical linkages between specific regional concerns (with societies such as those of Madagascar, or Borneo, or Oceania, or Micronesia) and the more general comparative concerns of anthropology that focus on the nature of society and of the human endeavour.

All of these efforts are in an early exploratory phase. They offer at best a set of goals - distant goals in a voyage of Austronesian exploration. Each of the volumes of the Comparative Austronesian Project has endeavoured to carry forward these efforts.

A feature of this volume is its examination of a range of new comparative issues in relation to place and landscape but, at the same time, it addresses various concerns considered in previous volumes of the Comparative Austronesian Project. Thus, for example, the organization and domestication of space, considered in Inside Austronesian houses, as well as ideas of origin and precedence, considered in Origins, ancestry and alliance, continue to be recognized as fundamental, related topics to be examined in relation to place.

\section{Current Interest in Place and Landscape}

The past several years has seen the publication of a number of collections of essays devoted to the consideration of place, space and landscape. These publications include the theme issue of Cultural Anthropology edited by Arjun Appadurai on "Place and Voice in Anthropological Theory" (1988), Barbara Bender's Landscape: politics and perspectives (1993), Eric Hirsch and Michael O'Hanlon's The anthropology of landscape: perspectives on place and space (1995), and Steven Feld and Keith H. Basso's Senses of place (1996). At an initial appearance, it might seem that the cumulative effect of these publications is to create a new focus within anthropology. However, what is most remarkable about reading the various papers in these collections - many of which are individually brilliant — is the diversity of perspectives, perceptions and philosophical orientations that are presented under a seemingly similar rubric. The rubric itself remains elusive. "Landscape" is thus variously represented as a topographic vista, as an intimate emplacement of local experiences, or as the "interanimation" of sense, speech and memory. Landscape, soundscape and ethnoscape vie with each other in the presentation of an ethnography of place. If there is to be an ethnography of place, it is a focus for study still in early efflorescence.

Moreover, if one considers the various papers in each of these different volumes, they portray a remarkable diversity of localities from Cibecue in east-central Arizona or Sawaieke on Gau in Fiji to the Roper Bar Police Reserve 
in the Northern Territory of Australia, or from Stonehenge to New Ireland, from Belfast or Vastergotland to North Carolina or eastern Madagascar. Each of these collections presents multiple visions of place, even as each volume's separate papers particularize a specific locality. Their impact is to stress the multiplicity of ways in which places are socially constructed and personally experienced.

By contrast to the contributions of those collections, there is one area Aboriginal Australia - where a concerted and well-focused consideration of country, place and landscape has had a significant impact and has transformed our ethnographic understanding. Recent research on place in the ethnography of Aboriginal Australia has in fact produced a coherent discourse that offers significant comparative perspectives.

Extending important insights first articulated by Stanner (1964), Strehlow (1970) and Munn (1970), a number of recent ethnographies have made landscape a central concern to the explication of local social knowledge. They include Fred Myers' Pintupi country, Pintupi self: sentiment, place and politics among Western Desert Aborigines (1986), Ian Keen's Knowledge and secrecy in an Aboriginal religion (1994), Howard Morphy's Ancestral connections: art and an Aboriginal system of knowledge (1991), and Nancy Williams' The Yolngu and their land: a system of land tenure and the fight for its recognition (1986).

The important feature of this research is the way in which landscape is shown to provide the underpinnings of a diverse array of social knowledge. Although the Austronesian ethnographic field differs markedly from that of Australia, this research in its coherence, comprehensiveness and potential comparative significance offers an example of how similar research might be pursued among Austronesian-speaking populations. It provides an important comparative reference.

The papers in the present volume portray particular places in the Austronesian-speaking world - for the most part, localities of little recognized significance. For several contributors, their papers represent their first publication and the first time that the locality they describe is given ethnographic representation. Although made up of individual papers, this volume, as a whole, is not intended to provide a scattering of separate visions of place. Rather, it endeavours to focus, in a tentative and exploratory way, on a few related ethnographic portraits, relying on a partially shared comparative framework directed to a common field of study. As such, this collection has been assembled with a view to considering whether there are common patterns to the ways in which place is represented among Austronesian-speaking populations. 


\section{Distinguishing and Valorizing Austronesian Spaces}

Implicit in this volume are a number of understandings and distinctions that derive from the field of Austronesian research and thus create a general background to a specific examination of place.

Of critical importance is the distinction, which figures prominently in several papers, between the ordering of space by directional co-ordinates and the specific identification of places within a locality. The ordering of space is fundamental to the creation of locative identities and to some extent reflects patterns of deixis that are a key feature of Austronesian languages. Although it is possible to distinguish various linguistic and social means by which such ordering is achieved, it is the historical embedding of this local creative process that is the prime concern.

Nils Bubandt, in his paper on the orientation system of the Buli of Halmahera, describes in detail the linguistic bases for this spatial orientation and he aptly designates the processes of deixis as a form of "spatial poesis". His paper examines how linguistic differentiation is relied upon to create a "moral space" in which cultural identities and local subjectivities find their appropriate place. He notes:

The "upward" domain is thus both socially and morally distinct from the rest of social space: it is the foreign, distant, the invitingly prosperous yet treacherous unknown.

A double process is involved in this spatial poesis. There is first a differentiation of space according to various co-ordinates and then there is the valorization of a particular co-ordinate or axis. Philip Thomas, in his paper on the Temanambondro of southeast Madagascar, notes a similar process of valorization of differentiated space. He writes that

the spatial articulation of hierarchy is principally played out through the cardinal points: north and east are respectively "above" (ambony) and therefore superior to south and west, themselves "below" (ambany).

Similarly my paper refers to the linguistic axes of spatial differentiation on the island of Roti as "symbolic co-ordinates". In the Rotinese case, such co-ordinates are linked to a conception of the island as a creature resting in the sea:

The island of Roti is conceived of as having a "head" (langa) and a "tail" (iko); a "right" side (kona) and a "left" side $(k i)$. The "head" of the island is in the east (dulu), its "tail" in the west (muli). The "right" side of the island is to the south, the "left" side to the north.

In this system, south and east are considered superior to north and west. Applying another set of directionals, one moves "upward" to the "head" of the 
island and "downward" to its "tail". Many names of specific places on Roti, especially in ritual reference, are based on these symbolic co-ordinates and assume a knowledge of their significance.

As Bubandt argues in his paper, such co-ordinates are more than an abstract reference system; they form the basis for social praxis. In some cases, as on Roti or in Madagascar, they provide for the orientation of houses and tombs and for the performance of rituals, the categorization of settlements and the evaluation of the directions of origin. (See Sudo 1996 for a particularly striking example of this for Micronesia.)

The indigenous peoples of Buru, discussed by Barbara Grimes, conceive of their island as a body. For them, the crucial directional axis is "upstream" (dae)/"downstream" (lawe). At the centre of the island is a lake (Rana). Grimes writes that since

the lake is as far "upstream" as one can go on the island, Rana is also a metonym for the interior of the island, symbolizing the cultural value of upstream over downstream, of the mountains over the coast.

This co-ordinate, with Rana at its centre, provides the basis for a more complex moral ordering:

An ordering of precedence thus flows from elder to younger, from upstream to downstream, from the headwaters in the mountains at the centre of the island to the periphery of the island at the coast.

In the general ethnographic literature, a great deal of attention has been given to Balinese directionals and their cosmological and personal significance. Like the system on Buru, the term kaja for the Balinese defines a propitious direction toward the interior of the island not, as on Buru, toward a lake, but to a mountain, generally that of Gunung Agung. By contrast, the term kelod refers to the less propitious direction toward the sea.

In a comparative examination of the western Austronesian directional systems, K. Alexander Adelaar (1997) identifies * Daya, "toward the interior" and * laSud, "toward the sea" as proto-Austronesian terms that define a "fundamental axis of orientation in Austronesian societies". The Balinese retain this orientation and the terms that define it are reflexes of the proto-Austronesian terms formed by the addition of $k(e)-$, "towards". The Buli, described by Bubandt, also make a similar distinction between "landside" and "seaside" but only the term for seaside, polau, reflexes * laSud. It is indicative that various Austronesian orientation systems preserve reflexes of proto-Austronesian terms but it is of more interest to consider the formal similarities among these various systems.

The directional systems that Adelaar describes for western Indonesia and Madagascar all appear to be "two-axis" systems. The alignment and designation 
of the two axes vary. Most such systems appear to have been relative orientation systems and may remain so, as for example on Bali. Whereas some systems have two relative axes, many align one axis with the rising and setting sun and allow only the second axis a relative alignment (to the mountain/sea, landward/seaward or upstream/downstream). Several of these systems, as for example on Java, have become fixed to represent the cardinal directions but even where these cardinal direction systems hold sway, local relative systems still persist. Hefner reports that some Tengger of East Java still retain a relative directional system that designates Mount Bromo, the mountain around which they are settled, by what is now the standard Javanese term for "south" (1985:68).

Most two-axis systems, as Adelaar has shown, can be "doubled" to create four-axis systems. This "doubling" appears to be a historical creation, possibly the result of Malay influence, since all four-axis systems share the same features and many similar lexical designations.

Equivalent comparative research on directional systems in eastern Indonesia has yet to be done. Many such systems, as for example those of the Rotinese and Timorese, are recognizable two-axis systems. Others appear to involve three axes. The Buli system described by Bubandt offers a good example of such a system but other such systems are also well documented (Forth 1991). The critical need is to examine how different directional axes, whatever their number, are combined with other topographic demonstratives and with particular verbs of motion to create the systems that local populations use in daily life (see Barnes 1988; Donohue 1995). The issue is therefore not one of predetermined stasis but of moving orientation within a specific landscape.

\section{Situating Place in a Narrated Landscape}

Although places may be located in relation to an oriented space, they are not the creation of the directional system by which they can be located. Specific places identified by name form a critical component of a social knowledge that links the past to the present. All the papers in this volume stress this point by noting, in different ways, the importance of narratives of the past in defining a landscape of specific places.

Andrew McWilliam, for example, describes an orientation system for the Atoni Pah Meto of Timor that is an analogue of that of the neighbouring Rotinese. With "head" to the east, which is referred to by a term for the rising sun, with "foot" to the west and the setting sun, and with north as "left" and "right" as south, this system implies a "prostrate human form with arms outstretched and the head oriented to the east". However, as he insists, this system is only "one type of cognitive map" by which people orient themselves. Relations to named places draw on a complex social discourse. The array of these places "projects the record of ancestral experience into the contemporary world". His paper goes 
on to examine the complex narrative traditions that are actively maintained by Meto groups.

Thus a landscape of places forms a complex structure of social memory. Quoting Fentress and Wickham in their study, Social Memory (1992), Roxana Waterson notes "the constantly recurring importance of local geography as a structure for remembrance". She makes evident that there is no simple structure of remembrance in Tana Toraja but rather different "contested landscapes of myth and history". Sandra Pannell, writing of the island of Damer in Maluku, emphasizes the same point: "The landscape, as narrated and geographic text, thus signposts forms of social behaviour, rights, responsibilities and relations." This "creation of place" she describes as a form of poesis by which "Mayawo narratives effect and recall ... simultaneously a construction of social identity and social relatedness." As she goes on to make clear, this poesis involves a two-way process because the "landscape also serves as the empirical foundation for the veracity of Mayawo stories in the same way that the narratives establish the authenticity of the cultural geography..." So, too, in the case of the Lelet of New Ireland, discussed by Richard Eves,

the narratives of the movements of larada [the territorial spirits of the Lelet] are the means through which the landscape is imaginatively fashioned, giving people identification and attachment to place.

Such narratives define significance and assign it to a landscape. Among Austronesians, water is regarded as fundamental to, and in many instances coterminus with, any specification of a landscape. As Thomas makes clear for the Temanambondro, the Manambondro River is "a constant feature of the environing landscape and a focal image in people's sense of place". The river both creates a common "origin" and differentiates among "ancestries" who are identified by separate tombs spatially arranged at its mouth. In a similar vein, Grimes reports for Buru that each ancestral founder is associated with a different river or stream, and house-circles derived from these founders establish themselves in an order of precedence that has a clear spatial embodiment.

McWilliam notes that among "a bewildering array of named places" on Timor, names marked by terms for water are notable because of the "importance of water sources for settlement sites". In their narrative recitations, Meto groups link the term "water" with that for "rock", invariably tracing their origin to some specific, usually striking, limestone outcrop. The same pattern is recognizable in Toraja. Waterson writes:

Features of a landscape such as mountains and rivers have a place in myth and oral histories, especially the genealogies and accounts attached to noble origin-houses. Some of these myths tell of founding ancestral 
couples ... of whom the man is said to have descended from the sky on to a mountain top, and married a woman who rose out of a river pool.

Not entirely unlike the traditions of the Toraja, the founding ancestor of the Gumai of South Sumatra, described by Minako Sakai, is believed to have descended to Earth on Mount Seguntang and married a princess from Bengkulu. Eventually his line produced nine sons. Each of these nine sons "followed one of the Nine Great Rivers that flow across South Sumatra to establish a new village".

As the papers in the volume indicate, the various narratives that define the landscape among Austronesian populations and give significance to specific places within it, share common patterns and thus produce a variety of notable resemblances. A prominent feature in many of these narratives is the recounting of a process of domesticating the landscape in which houses and settlements of origin figure prominently as do the memories of previous sites of residence (see Toren 1995 for an exemplary examination of the idea of ancestral sites in Fiji).

Equally prominent, as part of the same process, are narratives that define paths through the landscape, setting forth ancestral journeys or recounting the passage of objects from place to place.

\section{Topogeny: Social Knowledge in an Ordering of Places}

This volume introduces the notion of topogeny, the recitation of an ordered sequence of place names. Like genealogies, topogenies figure prominently among Austronesian populations but have not been recognized as a distinct means for the ordering and transmission of social knowledge. In so far as a sequence of names can be attached to specific locations in an inhabited landscape, a topogeny represents a projected externalization of memories that can be lived in as well as thought about.

Topogenies take a great variety of forms among Austronesian populations. They may recount the journey of an ancestor, the migration of a group, or the transmission of an object. In introducing the notion of topogeny, I have selected one from among a variety of topogenies recounted by Rotinese. It traces the transmission of rice and millet from the sea throughout the island and back to the sea again. Other forms of topogeny exist. Thus, for the population of Termanu, there is an important topogeny that describes the origin and wandering of two great rocks that eventually come to settle along the north coast of the island and become a defining feature of the landscape of the domain of Termanu.

McWilliam provides an excellent example of the most common form of topogeny among the Atoni Meto. This topogeny traces the migration (and expansion) of a "name group" or clan (kanaf) from its point of origin through the mountains and valleys of Timor. In its semantically condensed form, this 
kind of topogeny relates the entire history of a large group and its encounters with other groups as the wandering of a single person represented in narrative first person (see Rumsey 1996 for other examples of this kind of first person narrative). As in Rotinese topogenies, persons, places and objects merge as a recitation of names.

Pannell describes similar itineraries among the Mayawo as "a landscape criss-crossed by a multitude of significant pathways and punctuated by a number of noumenally important places". Instead of regarding these narratives as histories, she prefers the term "topostories". Waterson presents yet another form of topogeny, one that is inserted within a Toraja narrative which begins with creation and then goes on to recount the marriages of the male and female ancestors who populated Tana Toraja. After providing a genealogy of their descendants who spread out and founded houses throughout the land, the narrative embarks upon a litany of the names of the ancestors who resisted Bugis incursion. This litany identifies these ancestors not by their individual genealogies but in relation to specific places, thus moving in an ordered fashion through the Toraja landscape.

Examples of other topogenies, either in simplified or elaborate form, are recognizable throughout the Austronesian-speaking world. A particularly striking example is evident in narratives of Belau as described by Richard Parmentier in The Sacred Remains. His description of Belau's mythology links the two common Austronesian metaphors, that of the "path" with its "origin" to the botanic image of the growing and spreading "tree" that extends from its base. Parmentier writes:

The account of the origin of Belau (uchul a Belau) in both geographical and cultural senses is phrased in terms of the construction of a path (rael) along which motion takes place from a beginning point (uchul) at Lukes or Mekaeb to an ending point (rsel) at Oikull. The key word which appears in the phrases "origin of Belau" and "beginning of a path" is uchul, which means not only "origin" and "beginning point" but also more generally "source," "basis," "cause" and "reason." The basis for these extended meanings appears to be the meaning "tree trunk," so uchul is simultaneously the physical support for upper limbs and point at which growth originates (1987:132).

Equally remarkable are the cycles of origin accounts, provided by Joël Bonnemaison, of the itineraries of the first "white rocks" that circled the island of Tanna in Vanuatu, forming and shaping the land (tan). Many of these rocks came ashore and moved through the land along traditional paths in the mountains and valleys of the island, giving rise eventually to a complex geography of presently immobile stones, each with special characteristics. The knowledge of the many different pathways of these stones, the names of places along the 
pathways, the concentration and dispersion of the stones and the intimate knowledge of their powers constitute critical social knowledge for the population of Tanna $(1985,1987)$.

The creation of this world predated the emergence of the first men from stone. With the appearance of the first humans began the vegetative transformation of this initial stony world. Men are thus compared to trees that must be rooted in the earth. In the words of a Tanna man, as quoted by Bonnemaison: "Men were rooted to the soil but women were like birds who fly above the trees, only descending where they see good fruit" (1985:37). Bonnemaison describes this local pattern of path and place as a "paradigm of origins constituting an archetypal space at the beginning of the world" (1987:413). Most interesting, as well, is that this same paradigm involves a kind of prehuman domestication of space since the "houses" of the first rock beings are explicitly referred to as canoes (niko) that traverse both land and sea.

Less spectacular but no less significant are the topogenies of the Ilongot as noted by Renato Rosaldo in his accounts of local history. He writes:

Ilongots, in fact, care intensely about the relative sequence of a succession of events, but these excursions into the past are meticulously mapped onto the landscape, not onto a calendar (R. Rosaldo 1980:48).

As Michelle Rosaldo observed, each Ilongot settlement consists of

a core group of closely related families who are apt to share a common history of residence, having lived in close proximity over years of intermittent movement ... It is this history of co-ordinated moves ... that lends a settlement its viability as an ill-defined yet generally recognized and cooperating social group (1980:5).

The biographies of individuals follow the same topogenic pattern as do the migration histories of different groups:

People readily listed in succession the names of the places where they had "erected their houseposts" and "cleared the forest". This task was as culturally appropriate for them as listing the place names along any walk they took ... (1980:42).

More formal and more elaborate topogenies are characteristic of the populations of West Seram who recount extensive topogenies of the migration of ancestral groups throughout the island. These topogenies are represented as the growth of an immense banyan tree at the centre of the island that extends its branches laterally, putting down new roots from above and thus creating a tangle of trunks and branches (Boulan-Smit 1997). 
For the people of Koa on Palu'é, a small island off the north coast of Flores, Michael Vischer has recorded even more extended topogenies. At the end of every five to ten year ceremonial cycle, the Koa people recite a chant that recounts the voyage of the first ancestors who travelled from the "rim of the earth in the west" bringing with them "the black patola stone" that provides the primordial substance of the island. Like recitations on Timor or Roti, this chant is structured by formal parallelism and "consists of a series of some two hundred paired place names". Knowledge of the first of these names is restricted to ceremonial officiants, whereas the knowledge of the names of places within Koa is less restricted. In his analysis of this chant, Vischer carefully sets forth the path of these place names in terms of a three-axis set of directionals that indicate movement through the landscape of Koa (1992:92-106).

Examples of topogenies also abound among the populations of western Indonesia. Some of the most elaborate of these topogenies are to be found recorded in the written narrative traditions of Java and Bali. The earliest and best known of these recorded works is the Old Javanese kakawin, the Nägara Kĕrtāgama ("Ordered is the Realm") written in 1365 by the poet Prapañca. A large segment of this great text is constructed as the journey of the ruler, Hayam Wuruk, through his kingdom. Before this royal progress begins, the text recounts the names of some 107 distinct states and domains that like "stars and planets", form concentric "ring-kingdoms" around the royal realm. The journey of the Hayam Wuruk through his realm begins at the centre of Majapahit and moves eastward through an initial fourteen places to an assembly point at Kapulungan and then steadily onward through a succession of a hundred named places to a site on the Sampean River, Patukangan, where the itinerary of the ruler turns back, proceeding through a further forty-seven named places to enter once more the inner realm.

In total, the narrative recounts a succession of 162 places that together, by their great number, delineate the length and breadth of the kingdom and exalt the power of the ruler (see Pigeaud 1960 III:16-42, IV:29-115). Although a majority of the places named in this literary topogeny can no longer be identified, a sufficient number are recognizable. These names provide a clear indication that the journey followed an ordered sequence. The naming of these places seems to have constituted a litany of power and control.

Similarly, when power was lost, the Javanese and Balinese narrative traditionwould invoke an ordered litany of places in revolt. Thus in the Babad Dalem, when Sri Kresna Kapakisan, the ruler sent by the kingdom of Majapahit toestablish authority on Bali, is faced with insurrection, the Babad identifies theextent of this revolt through a recitation of more than fifty named villages. Inresponse to Sri Kresna Kapakisan's request for assistance, Gajah Mada sends forth from Majapahit to Bali his powerful kris, Ki Lobar (see I Wayan Warna et 
al. 1986; Wiener 1995:110). What the Babad focuses on is not an ensuing battle, but the journey of the Gajah Mada's kris from Majapahit via at least a dozen named points before reaching Samprangan on Bali. The journey of this weapon itself reinstates the power of the Balinese ruler.

Perhaps the most remarkable of these literary topogenies is to be found in the Serat Sekondhar, an eighteenth century Javanese narrative that would seem to be an attempt to incorporate and account for the European presence within a Javanese genealogical world. The text comes to an abrupt end with an invocation of "the spirits of Java, who watch over the lands ... great is their beneficent power. If they are all memorized, they will become a defense..." What follows is a litany of 142 spirits, identified by place names. This sequence of named places begins with Majapahit and moves progressively through East Java, then Central Java, along Java's north coast and on to West Java. Most of these places can be identified. The first hundred or so appear to follow a general progress whereas it is difficult to discern a geographical order to the remaining places as they are recounted (see Ricklefs 1974:403-407). Here the whole of Java, rather than just East Java as in the Nāgara Kĕrtāgama, forms the geographical template for a spirit topogeny whose memorization appears to have conferred power and protection.

\section{Varieties, Forms and Functions of Topogeny}

Even a brief survey of the topogenies one encounters among Austronesianspeaking populations suggests that it is a form that can take on various functions. As a sequence, a topogeny may focus on points of origin and termination and thus define a line of precedence. It may, as in the case of various migratory topogenies, also define a chronological succession of events and serve as an equivalent to genealogy. In such cases, a topogeny may provide the dimension of time but not the dimension of status generally associated with genealogy.

Elsewhere (Fox 1995a), I drew a general contrast between Austronesian societies characterized by "lateral expansion" and "apical demotion". Those societies with a capacity for "lateral expansion" have flexible, bilateral, largely egalitarian modes of social reckoning and generally possess sufficient territory to hive off and create new modular groups. By contrast, throughout the Austronesian world from Madagascar to Polynesia, there exist societies that are characterized by systems of "apical demotion" whereby an élite (and not necessarily the whole of the society) distinguishes itself through a process of status elevation that rigorously and automatically demotes those who become progressively distanced from a primary line of status holders. The élites in these societies rely on genealogy as a primary means of defining groups and distinguishing precedence among themselves. Societies in which groups are 
reproduced through lateral expansion can more aptly utilize topogenies to identify groups and trace continuity among them.

At best, this contrast serves to highlight differences among Austronesian populations. A majority of Austronesian populations rely on both genealogy and topogeny and many have no one form of topogeny but a variety of such forms. Transformations between topogenies and genealogies are also possible. Seen as historical documents, many elaborate Austronesian genealogies appear to have been topogenies that have been transformed into genealogies. Similarly, in those societies where the control of knowledge becomes restricted, topogenies serve as a device for the encoding of esoteric forms of knowledge.

The critical component of all topogenies are their topoi (or loci), which among Austronesians are variously referred to as "nodes", "joints", or "junctures" - using the metaphor of the growth of a plant or tree — or "gates", "halting places", or "meeting points" — using the metaphor of a journey. It is at these topoi that culturally significant knowledge is "stored". McWilliam makes this point explicit. Referring to Meto topogenies, which are expressed in ritual discourse (natoni) marked by parallelism, he notes:

Narratives such as these are in many ways only summary accounts which mark events with key verbal references that may represent tangential points for more detailed exegeses.

Topogenies thus merely provide a framework for the "placement" of more extended knowledge that can be called upon when necessary. Each place name offers the possibility for an elaboration of knowledge.

In form and function, topogenies resemble the mnemonic devices of the classic Western tradition of rhetoric and memory. Aristotle is identified as one of the founders of this tradition and the prime contributor to its different lines of development (Grimaldi 1974; Ochs 1974; Yates 1969). In his Rhetoric, Aristotle confined the use of the notion of topoi to a specification of "arguments" which he classifies by various schemes. In his Topics, however, he provided a basic statement of the relation of memory to an ordered sequence of these topoi or places:

For just as in the art of remembering, the mere mention of the places (topoi) instantly makes us recall the things, so these will make us more apt at deductions through looking to these defined premisses in order of enumeration (Topics: Bk VIII, Ch.14, 163:29-33).

As Frances Yates has shown, this passage and several others established the foundation for an intellectual tradition that flourished in the Middle Ages and has continued, in various guises, to the present (1969:42-113). This medieval "art of memory" or ars memorativa was based on an explicit formalization of 
links between "image" (or specific memory), "place" and "order", maintained through regular reiteration - all of which constitute the basic components of a topogeny. Unlike the Austronesian traditions considered in this volume, however, the Western medieval tradition removed its loci from living landscapes and located them instead in imaginary spheres that became new worlds, elaborate theatres or intricate palaces of memory.

Were one to confine consideration to forms of topogeny grounded within specific landscapes, it is apparent from the anthropological literature that topogeny is of near universal prevalence and, within the region, is of marked importance.

Jürg Wassman, for example, has provided an exceptionally striking example of topogeny among the western Iatmul of the village of Kandingei. As he stresses, critical to the recitation of the topogenies of important elder clansmen ("old crocodiles") is a "knowledge of relations and inter-connections" between "the events of primal times, the secret names of the primal beings and the totems as well as the places visited during the migration" (1991:61). As a further means to preserve the knowledge of these interconnections revealed in the topogenies, clan groups construct cords of various lengths consisting of a specific arrangement of large and small knots.

Wassman's monograph examines, in remarkable detail, a single topogeny: a mortuary performance by the Pulau clan group of a clan song-cycle that recounts the movement of the ancestral founder Walindambwi and the Palingawi crocodile through a succession of twenty sites, at which encounters occur with a "multitude of totemic objects, plants, animals and primal beings" (1991:163). The knotted cord, which serves as the mnemonic accompaniment of this topogeny, measures five metres in length and between each of its twenty large knots there are on average twelve smaller knots. The fact that much of this knowledge is esoteric and requires ambiguity and indirection in its annunciation further adds to the complexity of this construction. Wassman's account, however, provides considerable insight into the ordering of knowledge conveyed by this topogeny.

James Weiner describes a different form of topogeny in the song poetry of the Foi. Many of these songs "unfold a sequence of places" in memory of a deceased individual, often by focusing on the movement of that person as a hunter among the places he hunted during his lifetime:

... such chaining of place names in song discursively re-creates a person's life in spatial and temporal terms and preserves the sense of life's encompassing flow (1991:105-106).

Quoting Schieffelin who describes similar songs for the Kaluli, Weiner writes: 
it is possible with any song to construct a map of the region concerned, including hills, streams, gardens, sago stands, and other resources, and ... trace a history of the area (Schieffelin 1976:184).

It is of particular note that Weiner draws the inspiration for much of his analysis, including that of the Foi longhouse as an embodiment of memory, from Heidegger's notion of language as "the house of being", which is a modern-day metaphoric transformation of the classical idea of an imagined memory palace.

\section{Ambiguities and Indeterminacy of Place}

Writing about ideas of country among the Yolngu of North-East Arnhem Land in his study, Knowledge and secrecy in an Aboriginal religion, Ian Keen remarks: "Drawing a map of connections to country can give an impression of fixed, agreed areas and boundaries" (1994:101). Yet as he goes on to note, the opposite is more commonly the case. Key sites are often more important than boundaries. Ambiguity of definition and competition for control are also critical in claims to country. Keen, in particular, is concerned with the indeterminacies among complex semantic fields denoted by key categories such as "country", "group" or relation to ancestor or country among the Yolngu (1994:14).

The origin structures of the Yolngu consist of clusters of shared connections which may be extended or contracted depending on context. These connections link different social aggregates to various named countries with important named sites within them. Both groups and countries possess relations to ancestors and their actions, from whom they derive their origin and formation and thus ultimately their attributes, associations and sacra. Ceremonies are intended to trace these connections. Although in principle,

people whose countries were connected by ancestral travels formed "one group" (ba:purru wanggany, mala wanggany) with "one sacred object" (madayin wanggany) and "one ceremony" (bunggul wanggany),

as Keen explains, Yolngu regularly

discuss and argue about whether people were "one" (wanggany) and "the same" (balanya bili) or "separate" (ga:na) and "different" (wiripu); or both the same and different (1994:73-75).

Critical to this clustering of knowledge are "elbow" (likan) names. These are a "class of polysemous names, called out at key points in ceremonies" which signify "a wanggarr ancestor, a place, and a group" (1994:71). Claims to country can be made by reference to these likan names and it is the invocation of these names that propels the ceremonial enactment of a journey, along kinship lines, through a number of countries. Keen describes the performance of one such 
ceremony of the Dhuwa moiety, a Cloudy Water madayin ceremony, that lasted for thirty-three days. For this ceremony, its "power-man"

invoked the likan names of one Dhuwa country, changing the country every two days or so to include the majority of Yolngu Dhuwa groups ... the ceremony traced a journey from west to east across the northern part of north-east Arnhem Land from, and then back west along, the coast (1994:199).

There are multiple ways by which one country can be linked to other countries, thus creating what Keen calls a "string" of "links between countries and groups holding the countries, and the assertion of group identity through the possession of places and sacra" (Keen 1994:145). Relations along these strings can be both the "same" and "different" or in Keen's phrasing "similarity in overall forms ... differentiated by details" (Keen 1994:145).

Keen's work and that of Morphy (1991) provide useful models for considering Austronesian topogenies. Although few, if any, of these Austronesian topogenies may have the same densely embedded clustering of knowledge or the complex levels of secrecy and revelation of the Yolngu, they do share many formal features. Timor is criss-crossed by the topogenies of each clan or "name" group. The tracing of even a few of these topogenies across the landscape of Timor has yet to be done and an analysis of variations in recitation by different groups sharing the same name has also not been undertaken. Work of the sort that Bonnemaison has accomplished for Tanna (1987) needs to be repeated in other areas of the Austronesian-speaking world.

It is instructive to consider Rotinese topogenies in relation to those of the Yolngu. Each domain on Roti has a plethora of ritual place names. A person in any one domain will know the place names of the local domain in greater detail than those of other domains. In a recitation that traces a path through many domains, one or at best a few names will be invoked as emblematic of each outside domain, whereas the pathway through the local domain should include as many pertinent names as possible. Recitations are thus invariably the specific creations of local chanters.

Morphy has raised the question of time in relation to Australian topogenies, arguing, for example, that

place has precedence over time in Yolngu ontogeny. Time was created through the transformation of ancestral beings into place, the place being for ever the mnemonic of the event (1995:188).

This is by no means the case with all Austronesian topogenies. Some indeed may be "time-neutral" but a great variety can only be interpreted as a succession of events in time expressed according to their place of occurrence. As Renato 
Rosaldo (1980) and others have argued, this "spatialization of time" is not a denial nor an abrogation of time but a different mode of organization for memories of the past.

It is also of interest to note that among the Yolngu, body images - head, thighs, arms - are used to structure ceremonial songs (Tamisari 1997) and that tree images - root and branch - are similarly relied upon "as a symbol of the relations of one group to many others and of the distinct identity of the group" (Keen 1994:169). Much the same imagery is regularly invoked among Austronesian-speaking populations to represent relationships of similarity and difference. Tree imagery, in particular, is near universal for such purposes and one has only to read a general book, such as Corter's Tree models of similarity and association (1996), to recognize the continuing relevance of such imagery for the graphic representation of the agglomerative clustering of knowledge.

Perhaps most relevant of these images is that of the "path" or "journey" which invariably defines actions, transfers and transpositions. A comparative study of Austronesian "pathways", as an active mode for representation of relations and their transformation, should be the next step in the investigation of place, for which this volume marks a start.

\section{References}

Adelaar, K. Alexander

1997 An exploration of directional systems in West Indonesia and Madagascar. In Gunther Senft (ed.) Referring to space: studies in Austronesian and Papuan languages. Oxford: Oxford University Press.

Appadurai, Arjun

1988 Introduction: place and voice in anthropological theory. Cultural Anthropology 3(1):16-87.

Aristotle

1997 Topics: Books I and VIII. (Translated with commentary by R. Smith.) Oxford: Clarendon Press.

Barnes, Robert H.

1988 Moving and staying space in the Malay archipelago. In H.J.M. Claessen and David Moyer (eds) Time past, time present, time future: essays in honour of Professor P.E. de Josselin de Jong, pp.101-116. Dordrecht: Foris Publications.

Bender, Barbara (ed.)

1993 Landscape: politics and perspectives. Oxford: Berg.

Bloch, Maurice 
1995 People into places: Zafimaniry concepts of clarity. In E. Hirsch and M. O'Hanlon (eds) The anthropology of landscape: perspectives on place and space, pp.63-77. Oxford: Clarendon Press.

Bonnemaison, Joël

1985 The tree and the canoe: roots and mobility in Vanuatu societies. Pacific Viewpoint 26(1):30-62.

1987 Tanna: les hommes lieux. Paris: Editions de l'ORSTOM.

Boulan-Smit, Christine

1997 We of the Banyan: the Alune of Central West Seram. Unpublished PhD thesis, Department of Anthropology, Research School of Pacific and Asian Studies, The Australian National University, Canberra.

Corter, James E.

1996 Tree models of similarity and association. London: Sage Publications.

Donohue, Mark

1995 Demonstratives. Chapter 6 in The Tukang Besi language of Southeast Sulawesi, Indonesia. Unpublished PhD thesis, Department of Linguistics, Research School of Pacific and Asian Studies, The Australian National University, Canberra.

Feld, Steven and Keith H. Basso (eds)

1996 Senses of place. Santa Fe: School of American Research Press.

Fentress, J. and C. Wickham

1992 Social memory. Oxford: Blackwell.

Forth, Gregory

1991 Nagé directions: an eastern Indonesian system of spatial orientation. In O. Gron et al. (eds) Social space: proceedings of an interdisciplinary conference on human spatial behaviour in dwellings and settlements, pp.138-148. Odense: Odense University Press.

Fox, James J. (ed.)

1993 Inside Austronesian houses: perspectives on domestic designs for living. Canberra: Department of Anthropology, Research School of Pacific Studies, The Australian National University.

1995a Austronesian societies and their transformations. In P. Bellwood, J.J. Fox and D. Tryon (eds), The Austronesians: historical and comparative perspective, pp.214-228. Canberra: Department of Anthropology, Research School of Pacific and Asian Studies, The Australian National University. 
1995b Origin structures and systems of precedence in the comparative study of Austronesian societies. In P.J.K. Li, Cheng-hwa Tsang, Ying-kuei Huang, Dah-an Ho and Chiu-yu Tseng (eds), Austronesian studies relating to Taiwan, pp.27-57. Symposium Series of the Institute of History \& Philology: Academia Sinica 3. Taipei.

Fox, James J. and Clifford Sather (eds)

1996 Origin, ancestry and alliance: explorations in Austronesian ethnography. Canberra: Department of Anthropology, Research School of Pacific and Asian Studies, The Australian National University.

Grimaldi, William M.

1974 The Aristotelian Topics. In Keith V. Erickson (ed.) Aristotle: the classical heritage of rhetoric, pp.176-193. Metuchen, NJ: The Scarecrow Press.

Hefner, Robert

1985 Hindu Javanese: Tengger tradition and Islam. Princeton: Princeton University Press.

Hirsch, Eric and Michael O'Hanlon (eds)

1995 The anthropology of landscape: perspectives on place and space. Oxford: Clarendon Press.

Keen, Ian

1994 Knowledge and secrecy in an Aboriginal religion. Oxford: Clarendon Press. Morphy, Howard

1991 Ancestral connections: art and an Aboriginal system of knowledge. Chicago: Chicago University Press.

1995 Landscape and the reproduction of the ancestral past. In Eric Hirsch and Michael O'Hanlon (eds) The anthropology of landscape: perspectives on place and space, pp.184-209. Oxford: Clarendon Press.

Munn, Nancy D.

1970 The transformation of subjects into objects in Walbiri and Pitjantjatjara myth. In R.M. Berndt (ed.) Australian Aboriginal anthropology, pp.140163. Nedlands: University of Western Australia.

Myers, F.R.

1986 Pintupi country, Pintupi self: sentiment, place and politics among Western Desert Aborigines. Washington, DC: Smithsonian Institute Press.

Ochs, Donovan J. 
1974 Aristotle's concept of formal topics. In Keith V. Erickson (ed.) Aristotle: the classical heritage of rhetoric, pp.194-204. Metuchen, NJ: The Scarecrow Press.

Parmentier, Richard J.

1987 The sacred remains: myth, history and polity in Belau. Chicago: University of Chicago Press.

Pigeaud, Theodore G.Th.

1960 Java in the 14th century: a study in cultural history. 5 vols. The Hague: Martinus Nijhoff.

Ricklefs, Merle C.

1974 Jogjakarta under Sultan Mangkubumi, 1749-1792: a history of the division of Java. London: Oxford University Press.

Rosaldo, Michelle Z.

1980 Knowledge and passion: Ilongot notions of self and social life. Cambridge: Cambridge University Press.

Rosaldo, Renato

1980 Ilongot headhunting, 1883-1974: a study in society and history. Stanford: Stanford University Press.

Rumsey, Alan

1996 The personification of social totalities in Pacific oratory. Paper presented at the 1996 American Anthropological Association Meetings.

Schieffelin, Edward L.

1976 The sorrow of the lonely and the burning of the dancers. New York: St Martin's Press/St Lucia: Queensland University Press.

Stanner, W.E.H.

1964 On Aboriginal religion. Sydney: University of Sydney.

Strehlow, T.G.H.

1970 Geography and the totemic landscape in Central Australia: a functional study. In R.M. Berndt (ed.) Australian Aboriginal anthropology, pp.92140. Nedlands: University of Western Australia.

Sudo, Ken-ichi

1996 Rank, hierarchy and routes of migration: chieftainship in the Central Caroline Islands of Micronesia. In James J. Fox and Clifford Sather (eds) Origin, ancestry and alliance: explorations in Austronesian ethnography, pp.55-69. Canberra: Department of Anthropology, Research School of Pacific and Asian Studies, The Australian National University. 
Tamisari, Franca

1997 Body, vision and movement: in the footprints of the ancestors. Unpublished paper. University of Sydney (19 February 1997).

Toren, Christina

1995 Seeing the ancestral sites: transformations in Fijian notions of the land. In Eric Hirsch and Michael O'Hanlon (eds) The anthropology of landscape: perspectives on place and space, pp.163-183. Oxford: Clarendon Press.

Vischer, Michael P.

1992 Children of the black patola stone: origin structures in a domain on Palu'é Island, Eastern Indonesia. Unpublished PhD thesis, Department of Anthropology, Research School of Pacific Studies, The Australian National University, Canberra.

Wassman, Jürg

1991 The song to the flying fox. Boroko: Cultural Studies Division, The National Research Institute. (Translation of Der Gesang an den Fliegenden Hund. Basel: Basler Beiträge zur Ethnologie: 22. 1982.)

I Wayan Warna, Ida Bagus Gede Murdha, Dewa Gede Tjatera, Ida Bagus Maka and Ida Bagus Sinu (eds)

1986 Babad Dalem: Teks dan Terjemahan. Dinas Pendidikan dan Kebudayaan Propinsi, DATI I, Bali.

Weiner, James F.

1991 The empty place: poetry, space and being among the Foi of Papua New Guinea. Bloomington: Indiana University Press.

Wiener, Margaret J.

1995 Visible and invisible realms: power, magic and colonial conquest in Bali. Chicago: University of Chicago Press.

Williams, Nancy

1986 The Yolngu and their land: a system of land tenure and the fight for its recognition. Canberra: Australian Institute of Aboriginal Studies.

Yates, Frances A.

1969 The art of memory. London: Peregrine Books. (First published London: Routledge \& Kegan Paul, 1966.) 